\title{
THE CANON AND THE ICON: SOME REFLECTIONS ON CANON 82 OF QUINISEXT COUNCIL
}

Ioan COZMA*

Abstract: The following study adds to existing research dedicated to iconographic art. Iconographic art emerged from the desire to depict the Holy Bible in images, and from the doctrinal disputes regarding the nature of Christ, providing a way to defend and confess the Orthodox faith. The Quinisext Council of 692 elaborated on Canon 82 that prohibited the symbolic depiction of Christ as a lamb, stating that the only canonical representation of Him is in human form, a concept that became extremely important for salvation. That provision reflected the Orthodox dogma of the two natures and wills of Jesus Christ, as defined by the Ecumenical councils, and helped support the Fathers' stance in the iconoclastic controversy. Canon 82 is also applicable to the representations of Theotokos, and of any saint, who should be depicted in human form.

Keywords: holy canons, icon, sacred art, ecumenical council, Iconoclasm

In the canonical norms of the first millennium, the interest of the Fathers to elaborate on norms of the sacred art, especially on those of iconographic art, was not a priority. In reality, the Fathers of the first centuries were not at all eager to intervene in such matters. Their reluctance is not to be interpreted as a lack of interest in this subject, it rather ought to be seen through the lens of the issuing and elaboration of canonical norms. In fact, the norms were created to respond to pressing issues of the Church at that time. Their authors did not want to anticipate, but rather to combat the deviant behaviors and practices prevalent in their

* PhD., Rev., Visiting Professor, Oriental Pontifical Institute (Faculty of Oriental Canon Law), Rome, Italy. 
time, which were contrary to the Church's teaching and tradition.

The purpose of canons was to provide rules of faith and guidelines of grace in close relation to the faith that was professed by the synods, celebrated by the Liturgy and practiced by Christians everywhere. Therefore, as they relate to our research, the canons are the iconic expression of the concrete life of the Church, just like icons provide visual expressions of the Christian teaching and preaching. The Apostles first transmitted the teaching of Christ verbally, then in written form, and lastly they spread it among the Christian churches ${ }^{1}$. Thus the first phase of Christian iconography is to be found within its early tradition.

The finalization of the Bible's canon, particularly that of the New Testament led to a gradual evolution of iconographic representations, which were viewed as accurate interpretations of the Scripture, and not mere visual illustrations of $\mathrm{it}^{2}$. From this point of view, the genuine role of the icon has been to represent what the written text affirms ${ }^{3}$, thus becoming a warrant of this written text ${ }^{4}$, specifically of the canonical writings of the New Testament and not of early Christian circulations of apocryphal writings ${ }^{5}$. Canon 60 of the Holy Apostles emphasizes the Church's reaction to this matter. The Church went on to prohibit its clergy from exposing their audiences to "the spurious books of the

${ }^{1}$ Cf. Robert GRANT, The Formation of the New Testament, New York, Harper \& Row Publishers, 1965, p. 181.

${ }^{2}$ Lazar Puhalo, The Ikon as Scripture. A Scriptural and Spiritual Understanding of Orthodox Christian iconography, Dewdney (B.C. Canada), Synaxis Press the Canadian Orthodox Publishing House, 1970, p. 1.

3 The icon has been seen as an Evangelical language. The role of the painters, as the Fathers of the $7^{\text {th }}$ Ecumenical Council stated, is "to depict all that the Scriptures say, they are advocates of the learned". The Community of Saint John the Baptist (Kareas Monastery), What Do You Know About Icons? An Aesthetic, Historical and Theological Approach to the Icons of the Orthodox Church, Attiki (Gr.), Etoimasia Publications, 2001, p. 3.

4 The icon should be understood through the Bible, and the Bible reveals itself through the icon. Therefore, through the Bible we find the key to understanding the iconography. See L. PuHALO, The Ikon as Scripture ..., p. 23.

5 The guarantee of the authenticity of the evangelical message was presented analogically by the St. Paul in the Letter to Galatians (1: 8-9): "But though we, or an angel from heaven, preach any other gospel unto you than that which we have preached unto you, let him be accursed. As we said before, so say I now again, if any man preaches any other gospel unto you than that ye have received, let him be accursed". 
ungodly, as if they were holy, to the destruction of the people and of the clergy", and to punish disobedience with deposition from the holy priesthood. Furthermore, during this period the first norms were issued containing the canonical list of the biblical writings as follows: Canon 85 of the Holy Apostles (the first canonical list of the Bible); Canon 60 Laodicea (343) ${ }^{6}$; Canon 24 [c. 32 Pidalion] Carthage (419) ${ }^{7}$; Canon 2 of Athanasios the Great; Canon 1 of Amphilochius of Iconium ${ }^{8}$.

The second context of the evolution of iconographic art in the Church is related to doctrinal disputes. In this phase, the canonicity of an icon was dependant on how much of the Orthodox doctrine it expressed, as confirmed by the synods. The icon had thus far been seen as a way to defend and confess the true Orthodox faith, a dogmatic declaration before being confirmed in an Ecumenical Council.

Since early beginnings, symbols have played an important role in both the biblical and the doctrinal approach. The usage of symbols in iconography was due to the necessity of expressing that which at first was invisible or imperceptible, but became visible and perceptible through the spiritual lens. For this reason the Church of the first centuries created a coded language, using biblical symbols at first, then pagan ones, and even certain themes from Greek and Roman mythology, giving them, however, a new content ${ }^{9}$ or, moreover, inventing new ones especially from the $2^{\text {nd }}$ century onward ${ }^{10}$. The disclosing of these symbols was being reserved for those initiated in the Christian faith, capable of understanding and perceiving their real meaning. Perhaps for this reason one can understand why, prior to the Council of Trullo, the Church had tolerated the representation of Jesus Christ in forms and images, accepting them as

${ }^{6}$ Canon 60 presents a list with 22 writings of Old Testament and almost all those of the New Testament, excepting the Book of Revelation.

7 This canon presents a complete list of the writings of the New Testament with the following mention: "It has pleased the Synod to prohibit the reading of anything besides the canonical Scriptures in church under color of divine Scriptures".

8 Amphilochius called his list "a most truthful canon of the God-inspired Scriptures". Agapios / Nikodemos, The Rudder (Pidalion), Chicago, The Orthodox Christian Educational Society, 1957, p. 886.

${ }^{9}$ Leonid OusPENSKY, Theology of the Icon, vol. I, Crestwood, St. Vladimir's Seminary Press, 1992, p. 66.

${ }^{10} \mathrm{Cf}$. Michel QuenOT, The Icon - Window on the Kingdom, Crestwood, St. Vladimir's Seminary Press, 1991, p. 19. 
relevant symbols for the Christian' catechetic and didactic understanding. In the first centuries, the Church was confronted with intense debates concerning the legitimacy of the symbolistic representation of Christ $^{11}$, the main question being how could Christ, the Son of God and the Son of Man, be represented without offending God? He who cannot be represented in material image or form, but who should nonetheless be emphasized as divine and human in nature. Hence, the Christological controversies could be considered the start of a new vision (shift) in the iconographic depiction of Jesus Christ. The debates among the defenders of the conciliar Orthodoxy and the various heretical factions, as were the Monophysites, the Monotheletes and the Monoenergists - each with their own distinct interpretation of Christ's incarnation - reached a climax in the $6^{\text {th }}$ century ${ }^{12}$.

The Fifth Ecumenical Council of Constantinople (553) had a particular importance in this regard. The council condemned Origen and his followers, who were advocating a symbolic representation of Christ, and reiterated the biblical view on creation, based on a Christ grounded in space and time and on a view of history as linear progression leading to the Second Coming ${ }^{13}$.

Those were the circumstances that determined the orthodox painters to gradually abandon the metaphoric or symbolic depiction of Christ as a Good Shepard, lamb, fish, vine, Orpheus with a lyre surrounded by animals, a Roman senator shaved and surrounded by apostles; and to favor, instead, the physical reality of His presence on earth. In that regard, the symbols were subordinated to physical expression, thus occupying a secondary role.

In attempting to portray Christ's historicity, the icon painters of $5^{\text {th }}$ century used two testimonials dating from time of Jesus to support their arguments. One testimonial, as told by the writings of Eusebius Caesarea, is the statue of Christ made by a woman healed by Christ of her excessive blood loss (the statue was later destroyed by Julian the Apostate); the

${ }^{11}$ Cf. Idem, The Resurrection and the Icon, Crestwood, St. Vladimir's Seminary Press, 1997 , p. 43.

12 Cf. Elizabeth Zelenesky / Lela GiLbert, Windows to Heaven. Introducing Icons to Protestants and Catholics, Grand Rapids, Brazos Press, 2005, p. 108.

${ }^{13}$ Ibidem, p. 109-110. 
second is the Holy Mandylion, or Holy Napkin, the image of Christ imprinted miraculously on a linen cloth, which is revered as the first icon of Christ ${ }^{14}$.

However, in this period a new iconographic concept was born. Representative of this concept is the icon of Christ Pantokrator in St. Catherine Monastery on Mount Sinai, painted perhaps during the reign of the Byzantine emperor Justinian I (527-656), either in Egypt or Constantinople. This icon depicts Christ robed in a royal tunic, in his left hand he holds a closed Gospel book adorned with jewels while his right hand is raised in blessing and teaching, with two raised fingers, symbolizing his dual nature, and the other three folded down, symbolizing the Holy Trinity. A golden halo encircles his head, representing the divine energy that streams from him. The features on Christ's face are unevenly depicted to indicate the relationship between justice and mercy. One eye is said to reflect the judgement of God, the other to reflect his forgiveness ${ }^{15}$.

The Christ Pantokrator of Sinai is a testimony to the development of iconographic art in the Eastern Orthodox Church in the $6^{\text {th }}$ and $7^{\text {th }}$ centuries, although there is no evidence of any existing ecclesiastical or civil norms regulating sacred art, especially the representations of Christ, during this time.

The Christological controversies of the $7^{\text {th }}$ century, concerning the nature and the wills of Jesus Christ, led to the convocation of the Sixth

${ }^{14}$ Before of $5^{\text {th }}$ century, nobody mentioned this image. Evagrius ( $6^{\text {th }}$ century) is the first who spoke about it, called 'the icon made by God'. The tradition says that King Abgar, a leper, ruler of a small country between Tigris and Euphrates, send to Christ his servant Hannan with a letter, in which asked to Christ to come to Edessa to cure him of disease. Hannan was a painter and he was instructed by his king that in case of the refusing of Christ to come, he was instructed to paint an image of Christ and return with that to the king. Hannan encountered great difficulties in accomplishing this mission, due the vast crowds that kept him at a distance. Seeing that Hannan wanted to paint his portrait, Christ asked for some water. He washed his face and wiped it with a linen towel, on which his features remained imprinted. Christ gave it to Hannan. The linen was kept in Edessa until 944, when it was taken to Constantinople. After 1204, all traces of this relic were lost. E. ZELENESKY / L. GILBERT, Windows to Heaven ..., p. 110-111.

15 Ibidem, p. 115-116. For the description of the icon see also What Do You Know About Icons?..., p. 128-129. 
Ecumenical Council, assembled in Constantinople in the Domed Hall of the imperial palace (called in Troullos), between November 7, 680 and September 16, 681. The Council condemned Monoenergism and Monothelism as heresy, proclaiming that Jesus Christ embodies two energies and two wills: the divine and the human. Since the fifth and the sixth ecumenical councils dealt only with dogmatic matters, ten years later the council gathered again with the intention of resolving a series of ecclesiastical disciplinary issues. It was held in autumn of 692 (or 691) in the same place as the previous one and it issued 102 disciplinary canons; the Orthodox Church, however, never considered it a new council or synod, but a complementary assembly of the fifth and sixth (Quinisext), which continues to be frequently referred to as the Sixth Ecumenical Council ${ }^{16}$.

Particularly of this corpus is Canon 82, the first canonical norm that dealt with the manner of depiction of Jesus Christ. Any background information about the drafting of this norm has been lost ${ }^{17}$, nevertheless, we can easily note that the canon reflects the Orthodox dogma of Jesus Christ, as defined by the Council in $681^{18}$ :

"In some depiction of the venerable images, the Forerunner is portrayed pointing with his finger to a lamb, and this has been accepted as a representation of grace, prefiguring for us through the law the true Lamb, Christ our God. Venerating, then, these ancient representations and foreshadowings as symbols and prefigurations of truth handed down by the Church, nevertheless, we prefer grace and truth, which we have received as fulfilment of the law. Therefore, in order that what is perfect, even in paintings, may be portrayed before the eyes of all, we decree that henceforth the figure of the Lamb of God who takes away the sins of the world, Christ our God, should be set forth in images in human form, instead of the ancient lamb; for in this way we apprehend the depth of the humility of the Word of God, and are led to the remembrance of his life in the flesh, his passion and his saving death, and of the redemption which

${ }^{16}$ Cf. L. OusPensKy, Theology of the Icon ..., vol. I, p. 92.

${ }^{17}$ Cf. Kathleen Corrigan, "The Witness of John the Baptist on an Early Byzantine Icon in Kiev", in Dumbarton Oaks Papers, no 42/1988, p. 3, fn. 20.

18 Quenot states that the use of the word 'icon' is perhaps most appropriate from that moment in history where sacred images became an object of veneration for the entire Church. M. QuENOT, The Icon - Window on the Kingdom ..., p. 26. 
thereby came to the world." 19

The canon has a theological tenor rather than a juridical one. The introductory part of the canon describes the circumstance and the reason for which Jesus was depicted as a lamb: "this has been accepted as a representation of grace, prefiguring for us through the law the true Lamb, Christ our God".

The second part contains the disposition, prescribing the rule of conduct that must be henceforth followed by the painters depicting Jesus Christ: "we decree that henceforth the figure of the Lamb... Christ our God, should be set forth in images in human form, instead of the ancient lamb," followed by the theological argument of such decision, which emphasizes the importance of the human nature of Christ: "in this way we apprehend the depth of the humility of the Word of God, and are led to the remembrance of his life in the flesh, his passion and his saving death, and of the redemption which thereby came to the world." Thus, the Fathers of the council did not intend to impose the veneration of Christ's image $^{20}$, but to authenticate the change from symbol to image, accentuating the importance of His representation, not in a metaphoric or symbolic way, but in His full humanity, which is extremely important for salvation ${ }^{21}$.

The canon was drawn in an apodictic form, which did not mean to stipulate any sanction. Nevertheless, it is evident that any representation of Jesus Christ as a lamb must be rejected and declared uncanonical. Yet how should the artists who disregard this norm be treated? This is where

${ }^{19}$ For English translation of the canons of Council in Trullo I used George NEDUNGATT / Michael Featherstone (eds.), "The Council in Trullo revisited", in Kanonika, no. 6/1995, p. 45-185.

${ }^{20}$ The veneration of the icon has been stated by the antiphotian synod of 869-870 in Canon 3: "We ordain that the holy icon of our Lord be venerated in the same way as the book of Gospels [...] If one does not venerate the icon of Christ the Savior, let him not see His face at the Second Coming. In the same manner, we venerate and bring homage to the icon of His all-pure Mother, to those of the holy angels, painted as they are described in the words of Holy Scripture, and furthermore to those of all saints. Let those who do not to do this be anathema", L. OUSPENSKY, Theology of the Icon ..., vol. II, p. 212.

${ }^{21}$ Cf. Kenneth PARry, Depicting the Word: Byzantine iconophile thought of the eighth and ninth centuries, Leiden, 1996, p. 10. 
the concept of analogia legis comes into play, a canonical and juridical principle that allows for a regulating norm to be applied to an essentially similar case for which there is no preexisting legalized norm. An example of such similar norms are the two canons of the same Corpus Trullanus, which deal with sacred art: Canon $73^{22}$ - prohibiting the depiction or imprints of the image of the Cross on the ground; and Canon 79 prohibiting the definition and representation of the Virgin's ineffable childbirth after the manner of common ones similar to our own ${ }^{23}$. Both of them stipulate the excommunication for the laymen who disregard the norm, while the latter also calls for the deposition for the clerics.

The reason of the dissemination of Canon 82 could be better understood through the readings of Canon 81 of the same Corpus Trullanus $^{24}$, which condemns Theopaschism, a monophysit heresy

22 Trullan, Can. 73: "The life-giving cross has shown us salvation, we ought with all diligence to render fitting honor to that through which we have been saved from the ancient fall. Wherefore, paying reverence to it in mind and word and sentiment, we command that signs of the cross which have been set into the floor by certain persons should be erased completely, in order that the trophy of our victory may not be insulted by the trampling feet of those who walk upon it. We decree, therefore, that those who henceforth set the sign of the cross into the floor should be excommunicated".

${ }^{23}$ Canon 79: "In our confession that the divine birth-giving by the Virgin was without childbed, inasmuch as it took place without seed, proclaiming this to all the flock, we wish to submit to correction those who through ignorance do what is improper. Therefore, whereas certain persons are known to boil flour and give this to one another in honour, as it were, of the childbed of the immaculate Virgin-Mother, we decree that no such thing should be done by the faithful; for this is no honour to the Virgin, who beyond all understanding and reason bore the uncontainable Word in the flesh: that her ineffable birth-giving should be defined and represented after the manner of common ones similar to our own. Therefore, if anyone henceforth is found doing such a thing, if he is a cleric, he shall be deposed, if a layman, excommunicated". In fact, Canon 79 prohibits the artists to depict the Theotokos' childbed, i.e. laying and exhausted by the childbirth's pain, or washing Christ in a basin. See the commentary on this canon in Agapius / Nicodemus, The Rudder..., p. 383-384.

${ }^{24}$ Canon 81: "Whereas we have learnt that in certain lands the Trisagios hymn is sung with the addition, after the words 'Holy Immortal', of the phrase 'Who was crucified for us, have mercy upon us', though this was expunged from the hymn by the holy Fathers of old as being foreign to true piety, together with the wicked heretic who invented these words; we, confirming that which has been decreed by our holy Fathers of old, anathematize any persons who still, after the present decree, receive these words in their Churches or make additions to the Trisagios hymn in any other wise. If the transgressor of that which has been decreed is of sacerdotal rank, we command that he 
supporting the idea that God was crucified and died. The followers of this heresy went as far as appending the Trisagion hymn, adding after "Holy Immortal" the very words "who was crucified for us, have mercy upon us", further implying that only the divine nature of Christ had suffered. In this context, Canon 82 was promulgated to ensure that Christ had a real human body and a human death.

The presence of St. John the Baptist in icons, pointing his finger at Christ as human, not as a lamb, was considered very important in the Monophysitism controversy, because the Forerunner witnessed Christ's divinity, as well as His humanity. As matter of fact, a representative icon, which reflects the doctrine proclaimed in Canon 82, is the icon of St. John the Baptist from St. Catherine's Monastery at Mount Sinai (today in Kiev, at Museum of Western and Oriental Art), painted either in the middle or the end of $7^{\text {th }}$ century ${ }^{25}$. In this icon, St. John points over his right shoulder to a medallion bearing an image of Christ, while a medallion bearing an image of the Virgin appears over his left. In his left hand he holds a scroll inscribed with his own words: "Behold the lamb of God who takes the sins of the world" (John 1: 29) ${ }^{26}$.

Canon 82 played an important role during the iconoclastic controversy (726-787; 814-842), widely used and defended by the Fathers against those who believed that the depiction of Christ and of the saints went against the teaching of the church councils ${ }^{27}$. In the first iconoclastic period, one of the defenders of depiction of Christ in human form was St.

should be stripped of his sacerdotal dignity; if a layman or monk, that he should be excommunicated".

${ }^{25}$ Some scholars sustain the depiction of icon at the end of the $5^{\text {th }}$ century, others in $6^{\text {th }}$ century, instead Kathleen Corrigan affirms that is possible that the icon was produced around the time of the Council of 692, as a pictorial counterpart to the dogma proclaimed in Canon 82. See K. Corrigan, "The Witness of John the Baptist...", p. 2,11 .

${ }^{26}$ Ibidem, p. 2.

27 The iconoclasts refused to accept the authority of the Quinisext council, and they held a synod in 754 at Hieria, known as the iconoclastic council. As a matter of fact, many of iconoclasts did not know exactly Canon 82. This affirmation is based on declaration of a repentant iconoclast, Elisa, archypresbiter of the Church of Blacherne, who stated at the council of Nicea of 787 that hearing the text of Canon 82 determined him to turn back to Orthodoxy (Mansi 13, 41B). Stephen GERO, "The Byzantine iconoclastic movement: a survey”, in Études Théologiques, no 9/1990, p. 99, 103, fn. 50. 
John of Damascus (676-754), who demonstrated that the prohibition of depiction of God was perfectly valid in the Old Testament tradition since God was invisible, but now, in the New Testament, "God in His bowels of pity became in truth man for our salvation God became visible by taking our nature" 28 . Hence, the depiction of Christ is allowed, even necessary, because we do not worship matter, we worship God, the Creator of matter, who became matter for our salvation. This teaching was used by the Fathers of the Seventh Ecumenical Council of Nicaea (787) in the formulation of the dogmatic definition of the council ${ }^{29}$.

Although the Church of Rome was quite reserved in accepting the Quinisext Council ${ }^{30}$, there is evidence that the first condemnation of the

${ }^{28}$ St. IoAn Damaschinul, Dogmatica, Romanian transl. by Fr. D. Fecioru, Bucharest, Apologeticum, 2004, p. 155: "But besides this who can make an imitation of the invisible, incorporeal, uncircumscribed, formless God? Therefore, to give form to the Deity is the height of folly an impiety. And hence it is that in the Old Testament the use of images was not common. But after God in His bowels of pity became in truth man for our salvation, not as He was seen by Abraham in the semblance of a man, nor as He was seen by the prophets, but in being truly man, and after He lived upon crucified, rose again and was taken back to Heaven, since all these things actually took place and were seen by men, they were written for the remembrance and instruction of us who were not alive at that time in order that though we saw not, we may still, hearing and believing, obtain the blessing of the Lord. But seeing that not everyone has a knowledge of letters nor time for reading, the Fathers gave their sanction to depicting these events on images as being acts of great heroism, in order that they should form a concise memorial of them. Often, doubtless, when we have not the Lord's passion in mind and see the image of Christ's crucifixion, His saying passion is brought back to remembrance, and we fall down and worship not the material but that which is imaged: just as we do not worship the material of which the Gospels are made, nor the material of the Cross, but that which these typify".

${ }^{29}$ Cf. Hilarion Alfeyev, Orthodox Christianity: The History and Canonical Structure of the Orthodox Church, vol. I, Yonkers, St. Vladimir's Seminary Press, 2011, Kindle Edition, Kindle Location 945.

${ }^{30}$ Pope Sergius (687-701) refused to accept the canons of the Council in Trullo, invocating that some canons are against the good order of the Church. Pope Constantin (708-715) and Pope John VIII (872-882) accepted only those canons which are not in contradiction with the precedents canons, the decretals of Rome and the good customs. Instead Pope Adrian I (772-795), in a letter to Patriarch Tarasius of Constantinople (784-795), declared that he accepts the six councils alongside of all canons promulgated by them, in accordance with the divine and ecclesiastics rules. Cf. Dimitrios Salachas, Istituzioni di diritto canonico delle Chiese orientali, RomaBologna, Edizioni Dehoniane, 1993, p. 119. 
iconoclasm as heresy was made in Rome by Pope Gregory II (715-731) at the local synod of 727. Pope Gregory also mentioned Canon 82 in his letter to the Patriarch of Constantinople Germanus $(715-730)^{31}$.

In the second period of the iconoclastic controversy, St. Nikephoros the Confessor (Patriarch of Constantinople 806-815) and St. Theodore the Studite (759-826) supported the depiction of Christ in human form. According to St. Nikephoros, the depiction of Christ in human form, rather than His depiction in form of lamb ${ }^{32}$, as Fathers of the Council of Trullo had stated, corresponds to the truth. In the same manner, according to St. Theodore the Studite, the consequence of not representing Christ in a material image is to deny His existence in human form, further arguing that depicting Christ in human form does not refer to the representation of His nature, but of his hypostasis ( $\tau \tilde{\eta} \varsigma \quad \forall \pi o \sigma \tau \dot{\alpha} \sigma \varepsilon \omega \varsigma$ $\tau о \tilde{v} X \rho \imath \sigma \tau o \tilde{v})^{33}$.

The application of Canon 82 is not limited only to the depiction of Christ, but by extension, the limitation is likewise applicable to the representation of the Evangelists and any saints of the Church, who must be depicted with respect to the human character. Concerning the Evangelists, the commentators of the canon in Pidalion consider it no sin for the former to be depicted with human features even accompanied by the animals that prefigured them in the old $\mathrm{law}^{34}$. In such case symbols are permitted to accompany human representation of the Evangelists, thus playing a secondary role in the ensemble.

The same canonical principle has also been adopted by the Fathers of the Seventh Ecumenical Council in respect to the representation of the Birthgiver of God, who must be portrayed as a girl (i.e., as a damsel) and not as an ark, a rod, a candlestick or any object that had been previously used to represent Her. All those things that served to prefigure Theotokos

${ }^{31}$ Cf. L. OUSPEnSKY, Theology of the Icon ..., vol. I, p. 99.

32 S. NiCEPHORUS, "Antirrhetici tres adversus Constantinum Copronimum", in $P G 100$, col.422: "Jamque etiam definionibus divinisque canonibus proponi Christi imaginem typicam censuerunt; et humana quidem potius forma, ceu veritati congruentiore, quam agni, fieri, prisci illi qui sacram sanctamque synodum sextam celebrarunt a Deo inspirati Patres, nos docebunt".

${ }^{33}$ S. THEODORI STUDITAE, "Antirrhetici tres adversus Iconomachos", in $P G 99$, col. 433434; "De cultu sacrarum imaginum", $P G$ 99, col. 505-506.

${ }^{34}$ Agapius / Nicodemus, The Rudder..., p. 387, fn. 1. 
could be depicted roundabout of $\operatorname{Her}^{35}$.

As a closing statement, the main argument of Christ's depiction in human form, brought forth by the Holy Fathers, is His incarnation. But representing Him in the shape of man is only half the truth ${ }^{36}$. Canon 82 is designated to ensure that every icon illustrates this very important characteristic, reminding all of us that the one depicted is the Word of God. Indeed, the painters' task is to always keep in mind that Christ is truly both God and man, maintaining a balance between human image and divine prototype, between visible and invisible. Therefore, "Jesus Christ must be represented not as a man, but truth, that He is very God, must always be evident together with the truth that He is perfect man: for though he is 'the Son of man' (Mk 8, 31; see Dn. 7, 13), He is also 'the Christ, the Son of God' (Jn. 11, 27) and, 'in Him dwells the fullness of the Godhead bodily' (Col. 2, 9)" "37. Before the icon of Christ, the faithful are brought in direct contact with the grace and the hypostasis of Our Lord, we worship the God-man, the flesh (human nature) of the Lord that became the same with the God. Thus, in iconographic art, the symbols and the personal (human) representation have to be in a perfect synchronization; basically, the symbols invite the faithful to communicate with the Archetype - i.e., the depicted person ${ }^{38}$.

\section{References:}

1. Agapius / Nicodemus, The Rudder (Pidalion), Chicago, The Orthodox Christian Educational Society, 1957.

2. Alfeyev, Hilarion, Orthodox Christianity: The History and Canonical Structure of the Orthodox Church, vol. I, Yonkers, St. Vladimir's Seminary Press, 2011, Kindle Edition.

3. CORRIGAN, Kathleen, "The Witness of John the Baptist on an Early Byzantine Icon in Kiev", in Dumbarton Oaks Papers, no 42/1988, p. 1-11.

4. GERO, Stephen, "The Byzantine iconoclastic movement: a survey", in Études Théologiques, no. 9/1990, p. 95-103.

35 Ibidem, p. 387, fn. 1.

${ }^{36}$ Cf. L. PuHAlO, The Ikon as Scripture ..., p. 23.

${ }^{37}$ Ibidem, p. 23.

${ }^{38}$ Cf. What Do You Know About Icons?..., p. 4-5. 
5. GRANT, Robert, The Formation of the New Testament, New York, Harper \& Row Publishers, 1965.

6. Migne, Jean-Paul, Patrologia cursus completus. Series Graeca, tom 99, 100, Paris, 1860, 1865.

7. Nedungatt, George / Featherstone, Michael (eds.), "The Council in Trullo revisited", in Kanonika, no. 6/1995, p. 45-185.

8. OUSPENSKY, Leonid, Theology of the Icon, voll. I-II, Crestwood, St. Vladimir's Seminary Press, 1992.

9. PARRY, Kenneth, Depicting the Word: Byzantine iconophile thought of the eighth and ninth centuries, Leiden, 1996.

10. PuHALO, Lazar, The Ikon as Scripture. A Scriptural and Spiritual Understanding of Orthodox Christian iconography, Dewdney (B.C. Canada), Synaxis Press the Canadian Orthodox Publishing House, 1970.

11. Quenot, Michel, The Icon - Window on the Kingdom, Crestwood, St. Vladimir's Seminary Press, 1991.

12. Quenot, Michel, The Resurrection and the Icon, Crestwood, St. Vladimir's Seminary Press, 1997.

13. Salachas, Dimitrios, Istituzioni di diritto canonico delle Chiese orientali, Roma-Bologna, Edizioni Dehoniane, 1993.

14. St. IoAn Damaschinul, Dogmatica, Bucharest, Apologeticum, 2004.

15. [The Community of Saint John the Baptist (Kareas Monastery)], What Do You Know About Icons? An Aesthetic, Historical and Theological Approach to the Icons of the Orthodox Church, Attiki (Gr.), Etoimasia Publications, 2001.

16. Zelenesky, Elizabeth / GILBERT, Lela, Windows to Heaven. Introducing Icons to Protestants and Catholics, Grand Rapids, Brazos Press, 2005. 